\title{
Stefania Chiarelli e Godofredo de Oliveira Neto (Org.) - Falando com estranhos: o estrangeiro e a literatura brasileira
}

Rio de Janeiro: 7Letras, 2016

Sérgio de Sá

Quando pequeno, mamãe dizia: "Não fale com estranhos". Ao sair de casa, também era recomendável não aceitar presentes de desconhecidos. O maior temor, ah, o maior temor era a balinha, possível porta de entrada ao aparente doce mundo das drogas. O imperativo negativo estava claro. Perigo. Fuja do estranho. Evite o estranho. Ele, entretanto, não se distanciará de nós. Não em palavras.

Ao estrangeiro, coube mais boa vontade, mais curiosidade. Houve sempre uma tentativa de com ele conversar. De onde vem? Que língua fala? Gosta daqui? O que deixou lá? O estrangeiro supunha roteiro de aprendizado. Levava a uma ampliação de horizonte, de conhecimento. Tudo se encaminhava aparentemente para uma tentativa de mútua compreensão. Desde que o estrangeiro não fosse estranho.

No livro Falando com estranhos, estabelece-se conversa prolongada (de olho no gerúndio) entre o estranho e o estrangeiro. De dentro pra fora e de fora pra dentro das fronteiras do país. Não mais a casa da infância, mas a maturidade da rua literária, lugar de prazeres, riscos, dores e recompensas. Dividido em cinco partes, o volume aponta diversas perspectivas para encarar e incorporar o alheio.

Os organizadores, Stefania Chiarelli e Godofredo de Oliveira Neto, também estão entre os autores dos 17 textos que compõem o livro publicado pela 7Letras. De modo bastante sensível, Chiarelli percebe sons, ruídos, barulhos da ficção urbana de Samuel Rawet, judeu polonês que migra aos 7 anos de idade para o Brasil e se move à margem como um estrangeiro-estranho que escreve literatura brasileira.

Predominam no livro análises dos trabalhos de escritores brasileiros que montam sua ficção intramuros com a presença de personagens estrangeiros e - fenômeno mais recente - daqueles que se deslocam no exterior no corpo a corpo de um "luto cultural". Valendo-se dessa noção, Nelson H. Vieira percorre o panorama dos romances de exílio ou emigração. Por que viaja o

\footnotetext{
${ }^{1}$ Doutor em estudos literários e professor da Universidade de Brasília (UnB), Brasília, DF, Brasil. E-mail: sergiodesa40@gmail.com
} 
escritor brasileiro? Por que estar no lugar do estrangeiro?, pergunta-se. Entre os autores analisados, João Paulo Cuenca e Paloma Vidal.

Autora do romance Algum lugar, Vidal assina texto neste Falando com estranhos sobre a perda da origem. $\mathrm{O}$ termo se junta a deslocamento e migrações para abrir as portas do tema geral da antologia. Argentina de nascimento, Vidal quer descobrir o próprio. E esse encontro se dá em forma de linguagem: o português do Rio e o espanhol de Buenos Aires traçam o mapa do eu que se confunde. A origem deslocada pela imigração proporciona outras miradas sobre a identidade.

Se a noção de estranhamento ainda tem validade, ela sai da vida de volta para a página, em forma de personagens (não necessariamente numa combinação direta com os russos). Primeiro, no indígena que é considerado estrangeiro em sua própria terra, como bem ressaltam Claudete Daflon, ao observar a presença e o trabalho do imigrantecientista Noel Nutels na literatura e na vida literária brasileira, e Giovanna Dealtry, ao ler "corpo-território-identidade" na personagem Maína do romance Habitante irreal, de Paulo Scott. Já Godofredo de Oliveira Neto ficcionaliza o tema com violência sugerida, no conto "Outro", que encerra o livro.

Os gringos "de fato" são motivo óbvio de estranhamento, sejam os colonos alemães épicos de Josué Guimarães, examinados por Alcmeno Bastos, sejam os imigrantes árabes que "invadem" a América de Jorge Amado ou a Amrik de Ana Miranda, vistos respectivamente por Muna Omran e Maria Zilda Ferreira Cury. E, ainda, os muitos estrangeiros que estão na obra de Lima Barreto, conforme esclarece Beatriz Resende por meio de crônicas e do personagem Coleoni, de Triste fim de Policarpo Quaresma. Existe "uma espécie de identificação entre o autor e aqueles que deixaram seu país de origem e dificilmente encontram sintonia com alguma pátria, seja a que deixaram, seja aquela de que passaram a fazer parte" (p. 199). Esses estranhos estrangeiros e suas culturas esquisitas vão se aproximando para compor vasto panorama de narrativas.

$\mathrm{Na}$ abertura do volume, Silviano Santiago retoma a noção de "cosmopolitismo do pobre" para assinar o texto menos relacionado à literatura brasileira. Trata-se de um aporte culturalista que serve de abrealas para a amplitude e de (des)enquadramento para a diversidade dos escritos posteriores. Valendo-se principalmente de Stuart Hall, o crítico aponta os pressupostos teóricos que o levaram à criação daquela categoria analítica. Por meio de "gestos" de acolhimento do diaspórico e 
do trânsito incessante entre sinais agora trocados, refaz-se a possibilidade de dialogar com o estranho. Mesmo que mamãe não queira.

E o desembrulhar da balinha, o presente até então proibido, exibe "nossa" literatura estrangeira, tradução de riscos nem sempre calculados (exílio, aventura, fuga). Mas algumas vezes, sim, muito bem planejados, como aponta Paulo Roberto Tonani do Patrocínio na ideia do projeto Amores Expressos, em que escritores brasileiros foram enviados a outros países para viver e depois narrar. Autor e narrador, obrigados a experimentar o estranhamento, são agora estranhos(as) vítimas do silêncio local, nativo, autóctone. Calando com estranhos, por medo do desconhecido.

A outra ficção vem assinada por Daniela Versiani e traz o toque de extrema contemporaneidade a fim de coroar o livro. Escreve uma carta remetida "aqui" para um amigo que está "aí". O leitor fará as conexões com a atual crise migratória na Europa e seus refugiados "debaixo da janela". Fará também a ponte mais curta com o texto de Giovanna Dealtry. Ambas recordam o conto "A menor mulher do mundo", de Clarice Lispector. E com ele(a), espantam-se com o outro, pelo outro, sem o outro. Dealtry enxerga apropriação indébita na atitude do explorador francês Marcel Pretre diante da menor mulher do mundo, a quem ele nomeia de Pequena Flor. Versiani prefere enfatizar o horror de Pretre ao perceber que ela "decidiu coçar-se onde uma pessoa não se coça" (p. 249).

$\mathrm{O}$ estrangeiro-explorador nomeia e o nativo-explorado se coça. Ai, que preguiça: o nome Macunaíma coçando... O estrangeiro que migra para ser explorado encontra o nativo que agora explora. Bagunça dos diabos. E a obrigatoriedade de falar a língua do outro, para fins de comunicação mínima.

Para Ângela Maria Dias, em texto sobre o romance A um passo, de Elvira Vigna, estamos diante de um quebra-cabeça alegórico. "As hipóteses se multiplicam e se excluem, obrigando o leitor a uma espécie de montagem em que sempre falta uma peça no tabuleiro de xadrez, numa infindável progressão de lances" (p. 207). Nesse jogo entre o estrangeiro e a literatura brasileira, há tráfego de ideias, há tráfico de ideias. Quer dizer, existe uma constante instabilidade, um permanente estranhamento. Nas cartografias da globalização, nas heranças da tradição, nas narrações da memória, nas ficções do viajante.

Quando a sensação de não pertencimento tira a paz mesmo do retornado, querer um equilíbrio perfeito entre os dois polos será sempre um plano distópico. Ana Maria Vieira Silva vai aos agudás 
("brasileiros" que voltaram à África) de Um defeito de cor e A casa da água para compreender esse mar de solidão patriótica. Nos romances de Ana Maria Gonçalves e Antonio Olinto, respectivamente, são vislumbradas as relações entre história, memória e literatura, "campo de investigação que propicia uma série de incursões nas narrativas contemporâneas que têm se preocupado com esse gênero híbrido" (p. 188).

Se é híbrido, não pressupõe comunhão total. Não pode haver complementação. Daí a literatura ser felizmente um território tão propício a essas histórias. Que outro lugar de ambiguidade poderiam os estranhos habitar além da linguagem incomum da comunicação literária?

De maneira paradoxal, esse embate discursivo ganha certa estabilidade própria a cada gênero narrativo, mas não suficientemente estável se há densidade estética, propícia ao deleite que se derrama na cumplicidade do leitor - natural, naturalizado ou o estrangeiro que domine a língua ou tenha a sorte de uma tradução.

A capa de Falando com estranhos conta de uma correspondência antiga, de uma troca de experiências escritas. Tão longe, tão perto. O tom esmaecido não diz da pujança literária que a própria obra faz vibrar. A literatura brasileira cultiva a sua "lavoura arcaica", como ressalta Masé Lemos na leitura do romance homônimo de Raduan Nassar. E também semeia a sua colheita presente e futura, como aponta Eurídice Figueiredo nas narrativas de filiação de escritores judeus brasileiros: Noemi Jaffe, Michel Laub, Luis S. Krausz, Flávio Izhaki, Tatiana Salem Levy, Adriana Armony.

O recado dessa antologia de textos de professores de teoria literária e de literatura brasileira está dado. O estranho se apresenta como estrangeiro. A carta com o carimbo do Comissariado de Polícia anuncia a morte metafórica de mamãe. Não mais o enigma do desconhecimento. Agora é permitido falar com estranhos, caminhar pela areia movediça de nossas praias, aceitar os presentes literários do outro. Na existência absurdamente realista da sociedade brasileira, sejamos generosos, elegantes e - na medida possível das incongruências narrativas - sejamos também sinceros.

\section{Referências}

CHIARELLI, Stefania; OLIVEIRA NETO, Godofredo de (Org.) (2016). Falando com estranhos: o estrangeiro e a literatura brasileira. Rio de Janeiro: 7Letras, 2016. 